\title{
Epidemiology of pediatric spinal fractures; implications for injury prevention
}

\author{
M Al-Mohammadi, I Marwa, M Zamakhshary, K Al-bedah, S Al-enazi, A Al-Habib \\ From International Conference for Healthcare and Medical Students 2011 \\ Dublin, Ireland. 4-5 November 2011
}

\section{Introduction}

The epidemiology of traumatic spinal fractures in children was not well described in the developing world. Our objective was to describe the causes and mechanism of pediatric spinal injuries, the frequency of spinal cord injury, and their outcome in the pediatric population. This has significant implications for allocation of public health resources and development of prevention programs.

\section{Methods}

Retrospective chart review of all patients at or below 18 years of age who sustained spinal fractures from May 2001 to May 2009. They were identified through a database at level one-trauma center.

\section{Results}

One hundred and twenty cases of spinal fractures were identified. This constituted $3.2 \%$ of all pediatric injuries and $1.3 \%$ of traumas at all ages during the period of the study. Mean age was 13.5 years (males $83.8 \%$ ). There were more spinal injuries with increasing age. The mechanism of injury was significantly variable among different age groups $(\mathrm{p}=0.002)$. While Motor Vehicle Collision (MVC) was the commonest cause in the age groups from 12-15.9 yrs (59\%) and from 16-18 yrs (80\%), pedestrian injury was more common in the younger age groups of 0-5.9 yrs and 6-11.9 yrs at $38.5 \%$ and $42 \%$ respectively. Overall, MVC was the commonest mechanism of injury (60.8\%). Among MVC cases were seat belt status was known, $90.6 \%$ did not have seat belts on. Cervical spine was the most commonly affected level (55.8\%) with more than one affected spinal level in $23.3 \%$. Spinal cord injury was found in $36.7 \%$ of cases. Spinal surgery was performed in $46 \%$ of cases. The overall mortality was $8.4 \%$; half of them were pedestrian injuries. 20.8\% were discharged with neurological deficit.

King Saud University, Saudi Arabia

\section{Conclusions}

Our series is one of the largest to date in addressing pediatric spinal fractures. Our study raises significant concerns regarding safety on the roads given the high frequency of MVC and pedestrian injuries.

Published: 9 July 2012

doi:10.1186/1753-6561-6-S4-P8

Cite this article as: Al-Mohammadi et al.: Epidemiology of pediatric spinal fractures; implications for injury prevention. BMC Proceedings 2012 6(Suppl 4):P8.
Submit your next manuscript to BioMed Central and take full advantage of:

- Convenient online submission

- Thorough peer review

- No space constraints or color figure charges

- Immediate publication on acceptance

- Inclusion in PubMed, CAS, Scopus and Google Scholar

- Research which is freely available for redistribution
( Biomed Central

\section{Biomed Central}

(c) 2012 Al-Mohammadi et al; licensee BioMed Central Ltd. This is an Open Access article distributed under the terms of the Creative Commons Attribution License (http://creativecommons.org/licenses/by/2.0), which permits unrestricted use, distribution, and reproduction in any medium, provided the original work is properly cited. 